\title{
KLASIFIKASI KELAINAN PADA JANTUNG MELALUI CITRA IRIS MATA MENGGUNAKAN FUZZY C-MEANS SEBAGAI PENGAMBIL FITUR IRIS DAN KLASIFIKASI MENGGUNAKAN SUPPORT VECTOR MACHINE
}

\author{
Dian C. Rini Novitasari ${ }^{1}$, Muhammad Fahrur Rozi ${ }^{2}$, Rafika Veriani ${ }^{3}$ \\ ${ }^{1,2,3}$ Prodi Matematika, Fakultas Sains dan Teknologi, Universitas Islam Negeri Sunan Ampel Surabaya \\ Email: ${ }^{1}$ diancrini@uinsby.ac.id
}

\begin{abstract}
Iridology is a diagnosis of an iris that represents signs such as the color and structure of the iris. This study of iridology computerized by a system used in detecting the state of the heart designed. The steps such as the pre-processing, converting images from RGB to Grayscale, eliminating noise using the median filter, cropping, grouping using Fuzzy C-Means (FCM), detection edge using the Canny method and followed by extraction features using the Gray Level Co-occurrence Matrix (GLCM), and classification using Support Vector Machine (SVM). The iris sample of the patient is normal and abnormal. Iris data of patients who had heart defects were 20 images. The results of the detection system through iris images have an accuracy rate of $75 \%$.
\end{abstract}

Keywords: Iridologi, Fuzzy C-Means, Grey Level Co-occurrence Matrix (GLCM)

\begin{abstract}
Abstrak. Iridologi merupakan diagnosis sebuah iris mata yang merepresentasikan tanda-tanda seperti warna dan struktur dari iris sehingga didapatkan informasi tentang kesehatan seseorang. Penelitian ini tentang iridologi yang terkomputerisasi oleh sebuah sistem yang digunakan dalam mendeteksi keadaan jantung yang dirancang dengan langkah-langkah seperti pra-proseskonversi citra ari RGB menjadi Grayscale, penghapusan noise menggunakan median filter, pemangkasan, pengelompokan menggunakan Fuzzy C-Means (FCM), deteksi tepi menggunakan metode Canny dan diikuti fitur ekstraksi menggunakan Grey Level Co-occurrence Matrix (GLCM), serta klasifikasi menggunakan Support Vector Machine (SVM). Sampel iris pasien dalam keadaan normal dan tidak normal. Data iris pasien yang memiliki kelainan jantung sebanyak 20 citra. Hasil dari sistem deteksi kelainan Jantung melalui citra iris ini memiliki tingkat akurasi sebesar 75\%.

Kata Kunci: Iridologi, Fuzzy C-Means, Grey Level Co-occurrence Matrix (GLCM)
\end{abstract}

\section{Pendahuluan}

Penyakit pada manusia semakin hari semakin bertambah dan bermacam macam. Penyakit yang muncul semakin kompleks karena pola hidup manusia yang semakin memburuk (M. Cl 2018.). Salah satu organ vital manusia dan sering terserang penyakit yaitu jantung. Untuk memompa darah ke seluruh tubuh merupakan peran dari jantung. Melihat dari fungsi jantung yang amat penting bagi manusia maka resiko bagi orang yang memiliki kelainan jantung sangat besar bahkan berujung pada kematian (al. 2018).

Pada tahun 2014 Survei Sample Regristration System (SRS) di Indonesia menyatakan bahwasannya, Penyakit Jantung Koroner (PJK) salah satu diantara lantaran kematian tertinggi bagi semua umur sesudah stroke, yaitu 12.9\% , serta Data World Health Organization (WHO) pada 2012 menyatakan bahwasannya 17.5 juta manusia di belahan dunia meninggal dunia dikarenakan mengidap penyakit tersebut (K. Kesehatan and R. Indonesia 2018). Dari sekian orang yang meninggal dikarenakan penyakit kardiovaskuler sebesar (42.3\%) penyebabnya dari PJK serta (38.3\%) penyebabnya dari stroke (K. Kesehatan and R. Indonesia 2018).

Salah satu cara melihat kelainan jantung pada seseorang dapat dilihat dari iris mata. Melihat dari iris mata dapat diketahui kelainan atau gangguan pada jantung (E. M. K 2016). Pada iris mata kelaianan jantung dapat dilihat dari iris mata pada bagian kanan pupil (M. Cl 2018.). Untuk membedakan beberapa gejala yang biasa diliat dari iris kita biasa melihat menggunakan iridology chart seperti yang ditunjukkan pada Gambar 1. 


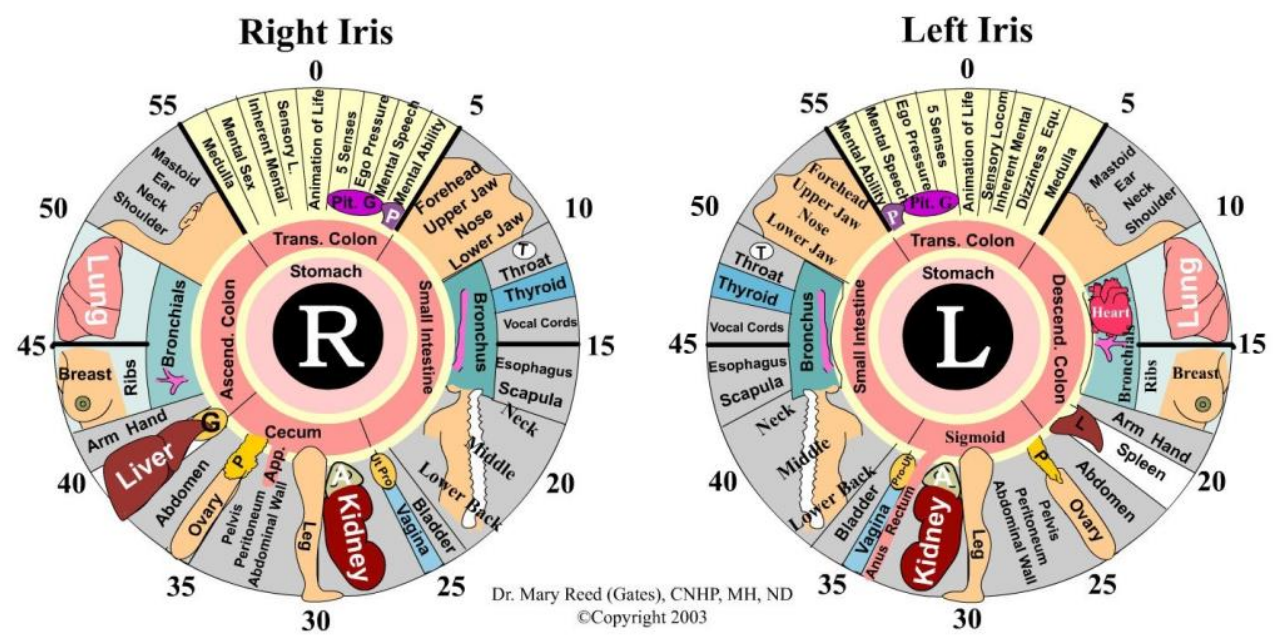

Gambar 1. Iridology Chart

Pengambilan fitur iris mata dapat dilakukan dengan menggunakan metode Fuzzy C-Means. Pada penelitian sebelumnya, Qonita Safitri melakukan pengambilan fitur batik menggunakan Fuzzy C-Means (FCM) serta Spatial Fuzzy c-Means (sFCM). Selain itu penelitian yang telah dilakukan oleh S.Jayalakshmi yang judul penelitiannya yaitu A Study of Iris Segmentation Methods using Fuzzy C-Means and K-Means Clustering Algorithm, Fuzzy C-Means juga digunakan sebagai metode untuk mengambil fitur pada citra iris. Pada penelitian yang lain M. Mentari melakukan pengambilan fitur pada citra daun tebu dengan menggunakan metode Fuzzy C-Means sebagai metode untuk pengambilan fitur (S.Jayalakshmi 2014).

Hasil dari pengambilan fitur menggunakan Fuzzy C-means, membutuhkan ekstraksi fitur untuk mengambil beberapa ciri dari fitur yang diperoleh. Ekstraksi fitur pada citra dapat memakai metode GLCM atau disebut dengan Grey Level Co-occurrence Matrix. Pada penelitian yang dilakukan Tallapragada dengan judul penelitian Iris Recognition Based on Combined Feature of GLCM and Wavelet Transform, menggunakan GLCM untuk ekstraksi fitur pada iris, menggunakan GLCM sebagai metode yang digunakan untuk ekstraksi fitur pada citra iris untuk menggabungkan fitur GLCM dan metode lainnya. (Anatomy 2010)Ekstraksi fitur menggunakan GLCM juga digunakan untuk pengambilan fitur pada citra sel serviks (R. F. Walker t.thn.).

Dari pengambilan fitur yang diperoleh, nilai fitur yang didapat bisa digunakan sebagai pengenalan untuk melakukan klasifikasi pada penderita kelainan jantung. Untuk melakukan klasifikasi dapat menggunakan metode SVM. Metode SVM saat penelitian sebelumnya digunakan untuk melakukan deteksi gangguan jantung dengan komputerisasi iridologi pada penelitian yang dilakukan oleh Lintang Indah Permatasari (Lintang Indah Permatasari 2016). Selain itu metode SVM juga digunakan untuk melakukan klasifikasi tumor otak pada penelitian yang dilakukan oleh J. Zhou (J. Zhou 2005). Metode SVM digunakan juga pada penelitian yang lainnya untuk melakukan klasifikasi gambar histogram.Dari beberapa acuan dan penjelasan tersebut, pada penelitian ini akan melakukan deteksi kelainan jantung melalui citra iris mata dengan pengambilan fitur menggunakan Fuzzy C-Means, dan memakai Metode Grey Level Co-occurrence Matrix (GLCM) untuk melakukan ekstraksi fitur, dan klasifikasi menggunakan SVM.

\section{Tinjauan Pustaka}

\subsection{Iridology}

Iridologi merupakan diagnosis sebuah iris mata yang merepresentasikan tanda-tanda seperti warna, serta struktur dari iris sehingga didapatkan informasi tentang kesehatan seseorang. Iris mata terletak tepat di depan lensa memiliki bentuk seperti jaringan cakram yang melingkar, dimana jaringan tersebut terdiri dari selaput otot sirkuler dan radial. Pada bagian tersebut terdapat pigmen yang berperan dalam mengatur warna mata. (S. Kumar 2015) 
Iridologi pertama kali dicetuskan oleh fisikawan yang berasal dari Hungaria yang bernama Ignatz von Peczely, sekitar tahun 1800 ketika Ignatz von Peczely mengamati perubahan pasiennya yang sembuh dari penyakit (E. M. K 2016). Ignatz von Peczely juga menjadi orang pertama yang menciptakan Iris chart, yang kemudian disempurnakan oleh dr Bernard Jensen supaya memudahkan pehaman seseorang terhadap iris mata (E. M. K 2016). Untuk melihat pembagian indikasi kesehatan di beberapa organ dalam tubuh dapat melihat Iris chart. Untuk melihat kelainan yang terjadi pada jantung dapat melihat iris mata pada bagian kanan iris mata kiri atau pada bagian kiri iris mata kanan seperti yang tertera pada gambar 1. (P. Matriks t.thn.)

\subsection{Grayscale}

Citra grayscale atau skala keabuan, warna abu-abu pada citra grayscale merupakan warna RGB (Red, Green, Blue) yang memiliki intensitas sama.Grayscale sendiri merupakan citra yang nilai dari setiap pixelnya adalah sampel tuggal. Intensitas Intensitas sebuah citra grayscale tersimpan di 8 bit integer dengan 256 peluang yang terjadi, diawali dari level 0 hingga 255 yang mana 0 untuk yang hitam serta 255 untuk yang putih sedangkan untuk nilai yang lainnya merupakan derajat keabuannya (Yang 2016)

\subsection{Adaptive Histogram Equalization}

Adaptive Histogram Equalization adalah suatu metode dalam memperbaiki kekontrasan pada citra dengan melakukan peningkatan kontras lokal sebuah citra. Lokal citra diperoleh dari region size yaitu grid yang simetris pada citra yang harus dibentuk terlebih dahulu. Regional citra digolongkan menjadi beberapa bagian yakni corner region atau CR yang merupakan bagian yang letaknya di sudut citra, border region atau BR yang merupakan bagian tepi namun kecuali CR, serta bagian yang letaknya di tengah disebut sebagai inner region atau IR (Freyssenita Kanditami P 2014).

\subsection{Median Filter}

Median filter digunakan untuk menghilangkan noise yang ada pada sebuah citra. Filter tersebut berfungsi pada operasi nonlinear yang nilai pixelnya diambil dari nilai pixel yang terdapat disekitarnya. Perhitungan tersebut dapat dilakukan dengan memilah kelompok dari nilai intensitas piksel selanjutnya mengganti nilai piksel yang diproses oleh nilai rata rata-rata yang berasal dari hasil urutannya (M. R. Pokorny et al., Prospective study of diagnostic accuracy comparing prostate cancer detection by transrectal ultrasound-guided biopsy versus magnetic resonance (MR) imaging with subsequent mr-guided biopsy in men without previous prostate biopsie 2014)

\subsection{Canny Edge Detection}

Metode Canny adalah satu diantara algoritma tepi modern. Canny pertama kali diperkenalkan oleh John Canny (1986) (P. Soepomo 2014.). Proses deteksi tepi dengan metode canny didapatkan dari operasi konvolusi. Konvolusi adalah proses memanipulasi citra menggunakan eksternalmask supaya didapatkan citra yang baru. Matriks kernel gaussisan diperoleh dari persamaan 1 di bawah ini:

$$
\mathrm{G}(\mathrm{i}, \mathrm{j})=\text { c. } \mathrm{e}-\frac{(i-u)^{2}(j-v)^{2}}{2 \sigma^{2}}
$$

Dimana:

$\mathrm{G}(\mathrm{i}, \mathrm{j}) \quad=$ element matriks kernel gauss pada posisi $(\mathrm{i}, \mathrm{j})$

$\mathrm{u}, \mathrm{v} \quad=$ penanda tengah matriks dari kernel gauss

$\mathrm{C}$ dan $\mathrm{e} \quad=$ konstanta

\subsection{Fuzzy C-Means}

Sejarah Fuzzy C-mean (FCM) awal mulanya diciptakan oleh J.C. Bezdek (1981). FCM merupakan salah satu metode yang digunakan untuk mengcluster atau membagi suatu data menjadi beberapa kelas [24]. Metode ini dimulai dari penentuan pusat cluster terlebih dahulu, selanjutnya pusat cluster tersebut serta derajat keanggotaanya diperbaharui pada setiap iterasi secara berulang. Algoritma FCM yaitu seperti di bawah ini: 
1. Lakukan penginputan data yang diklasterkan $X$, yang merupakan matriks dengan ukuran $n$ $\mathrm{x} \mathrm{m}$

$\mathrm{n}=$ jumlah sampel data

$\mathrm{m}=$ atribut setiap data).

Xij = data sampel ke-i $(i=1,2, \ldots, n)$, atribut ke-j $(j=1,2, \ldots, m)$.

2. Selanjutnya tentukan :

Jumlah cluster (c), bobot (w), Maksimum iterasi (MaxIter), Error terkecil yang diinginkan, fungsi objektif awal $(\mathrm{P} 0=0)$, dan Iterasi awal $(\mathrm{t}=1)$.

3. Tentukan bilangan randomnya $\mu \mathrm{ik}, \mathrm{i}=1,2, \ldots \mathrm{n}$; dan $\mathrm{k}=1,2, \ldots, \mathrm{c}$ untuk elemen dari matriks partisi awal U. Hitung jumlah dari setiap kolom menggunakan persamaan 2.

$$
\mathrm{Q}_{\mathrm{i}}=\sum_{k=1}^{c} \mu_{\mathrm{ik}}
$$

Selanjutnya dapat menghitungnilai $\mu_{\mathrm{ik}}$ dengan persamaan 3 .

$$
\mu_{\mathrm{ik}}=\frac{\mu_{\mathrm{ik}}}{\mathrm{Q}_{\mathrm{i}}}
$$

4. Lakukan perhitungan pusat cluster ke-k

$$
\mathrm{V}_{\mathrm{kj}}=\frac{\sum_{i=1}^{n}\left(\left(\mu_{\mathrm{ik}}\right)^{\mathrm{w}} * X_{\mathrm{ij}}\right)}{\sum_{i=1}^{n}\left(\mu_{\mathrm{ik}}\right)^{\mathrm{w}}}
$$

5. Lakukan perhitungan fungsi objektif pada iterasi ke-t

$$
\mathrm{Pt}=\sum_{i=k}^{n} \sum_{k=1}^{c}\left(\left[\sum_{j=1}^{m}\left(X_{i j}-V_{k j}\right)^{2}\right]\left(\mu_{\mathrm{ik}}\right)^{w}\right)
$$

6. Lakukan perhitungan perubahan Matriks Partisi

$$
\mu_{\mathrm{ik}}=\frac{\left[\sum_{j=1}^{m}\left(X_{i k}-V_{k j}\right)\right]^{2}}{\sum_{k=1}^{c}\left[\sum_{j=1}^{m}\left(X_{i j}-V_{k j}\right)^{2}\right]}
$$

7. Lakukan penecekan kondisi berhenti :

Apabila : $(|\mathrm{Pt}-\mathrm{Pt}-1|<\varepsilon)(\mathrm{t}>$ MaxIter) maka akan berhenti;

Apabila : $\mathrm{t}=\mathrm{t}+1$, ulangilah tahapan ke-4.

\subsection{Grey Level Co-occurrence Matrix (GLCM)}

Teknik dalam GLCM dapat disebut juga dengan spasial tingkat abu-abu matriks, GLCM merupakan sebuah matriks persegi ukuran $\mathrm{G}$ x G, di mana $\mathrm{G}$ adalah jumlah abu-abu tingkat dalam gambar. Setiap elemen $(i, j)$ dalam matriks yang dihasilkan hanya jumlah dari berapa kali pixel dengan Intensitas I (I nilai berkisar dari 0 hingga 255). Probabilitas gabungan terjadinya co-gray level a dan b untuk dua piksel dengan hubungan spasial yang ditentukan dalam suatu gambar dihitung (hubungan spasial didefinisikan dalam hal jarak $\mathrm{d}$ dan sudut $\theta$. Nilai $\mathrm{d}$ biasanya tetap kecil, dan sering diekspresikan dalam bentuk $(\mathrm{d}, \theta)$, dengan $\mathrm{d}$ mewakili garis Jarak dalam piksel, dan $\theta$ sudut di antara keduanya. Jenis ciri yang dapat diekstraksi oleh matriks kookurensi adalah sebagai berikut [12] :

1. Energi

$$
\mathrm{f} 1=\sum_{i=1}^{n} \sum_{j=1}^{m} P(i, j)^{2}
$$

2. Homogen

$$
\mathrm{f}_{2}=\sum_{i=1}^{n} \sum_{j=1}^{m} \frac{P(i, j)}{1+(i-j)^{2}}
$$

3. Korelasi

$$
\mathrm{f}_{3}=\sum_{i=1}^{n} \sum_{j=1}^{m} \frac{(i, j) P(i, j)-\mu^{2}}{\sigma_{x} \sigma_{y}}
$$

4. Contrast

$$
\mathrm{f} 4=\sum_{i, j=0}^{n-1} P(i, j)(i-j)^{2}
$$

Rata-rata dan standar deviasi sebagai primer fitur serta korelasi berasal dari sini, sebagai korelasi merupakan probabilitas kejadian antarwarna. Varians statistik adalah ukuran heterogenitas dan berkorelasi kuat dengan variabel statistik orde pertama sebagai standar deviasi. Sedangkan Varians meningkat ketika level abu-abu. Inersia dan Auto-Correlation mewakili piksel tingkat dan tingkat ketergantungan warna (P. Mohanaiah 2013.).

\subsection{Support Vector Machine}


Support Vector Machine (SVM) pertama kali didengar oleh masyarakat umum pada tahun 1992 yang mulanya diperkenalkan oleh Boser, Guyon, dan Vapnik di COLT-92. Klasifikasi menggunakan SVM dan juga pemilihan fitur, keduanya dapat mengidentifikasi set yang terlibat dalam proses untuk membedakan kelasnya. Tujuan SVM yaitu memisahkan data dengan hyperplane serta memperluasnya menjadi nonlinier dengan batasnya memakai trik kernel (Lintang Indah Permatasari 2016).

\subsection{Confusion Matrix}

Confusion Matrix merupakan salah satu metode yang dapat digunakan untuk menggambarkan nilai keberhasilan dari pengujian peneltian. Pengambilan nilai keberhasilan suatu percobaan dapat dilihat dari nilai akurasi yang diperoleh. Metode Confusion matrix menghitung nilai akurasi dari sebuah pengerjaan dengan bantuan matrix [9]. Matrix yang dibentuk dengan metode ini di tampilkan pada Gambar 2.

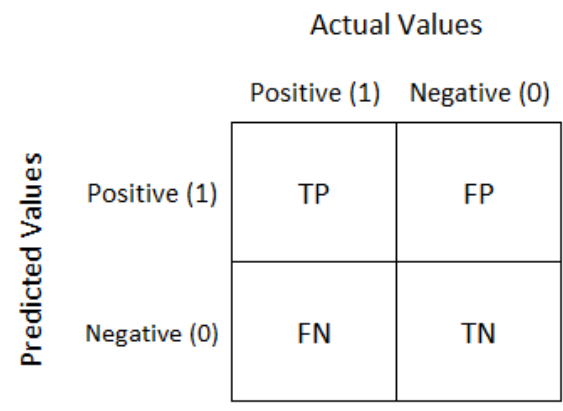

\section{Gambar 2. Bentuk Confusion Matrix}

Pembentukan matriks confusion, dilakukan dengan menghitung jumlah hasil perhitungan benar dan salah. Setelah mendapatkan nilai matriks tersebut, dapat dilakukan penghitungan nilai akurasi. Perhitungan dilakukan dengan menjumlah nilai pada diagonal utama matriks dibagi dengan jumlah keseluruhan nilai pada matriks, atau busa ditulis seperti pada persamaan 11.

$$
\text { Akurasi }=\frac{\sum_{i=1}^{m} M_{i, i}}{\sum_{i=1}^{m} \sum_{j=1}^{m} M_{i, j}} \times 100 \%
$$

Dengan :

$\mathrm{M}=$ Matriks Confusion dengan ukuran $\mathrm{mxm}$

\section{Metode Penelitian}

Pada penelitian ini menggunakan data berupa citra iris yang diperoleh dari pengambilan foto iris pasien yang akan diperiksa kesehatan jantungnya. Citra iris dengan penderita kelainan jantung sementara berjumlah 20 citra. karena citra iris yang didapat dari hasil pemotretan merupakan citra RGB, maka citra yang diperoleh dirubah terlebih dahulu menjadi grayscale. Pengubahan dari RGB menuju grayscale bertujuan untuk memperkecil skala yang dimiliki oleh suatu citra dan mendapatkan suatu nilai yang mewakili dari setiap pikselnya dengan jelas. pada proses selanjutnya untuk memperbaiki citra diperlukan penghapusan noise pada setiap citra. Diagram alur proses penelitian ini dapat dijelaskan melalui Gambar 3.

Penghapusan noise noise pada citra dapat dilakukan menggunakan metode median filter. Menggunakan median filter nilai nilai piksel yang dapat mengganggu pembacaan suatu citra akan diperbaiki ataupun dihapus. Ganguan atau noise yang timbul dalam suatu citra dapat terjadi karena debu debu yang menempel pada kamrea pengambil gambar iris, ataupun gangguan yang terjadi akibat makhluk hidup lain. 
Setelah citra iris sudah dilakukan pembersihan dari noise, citra dapat dilakukan pengambilan filter menggunakan fuzzy c-means. Menggunakan fuzzy c-means nilai nilai piksel yang dimiliki citra iris akan dikelaskan menjadi beberapa kelas. Pengkelasan nilai piksel pada citra akan membedakan nilai piksel yang menjadi bacgound dan nilai piksel yang menjadi fitur iris. dari proses pengkelasan yang dilakukan menggunakan fuzzy c-means selanjutnya akan dilakukan deteksi tepi untuk mendapatkan pola dari fitur yang didapat. Pada penelitian ini deteksi tepi dilakukan menggunakan metode canny. Metode canny edge detection akan membaca setiap tepi dari gambar yang diproses. Dari deteksi tepi akan diketahui pola pada iris mata yang sehat maupun iris mata yang menunjukkan kelainan jantung. Menggunakan pola pola yang diperoleh akan mempermudah komputer untuk mengenali suatu citra.

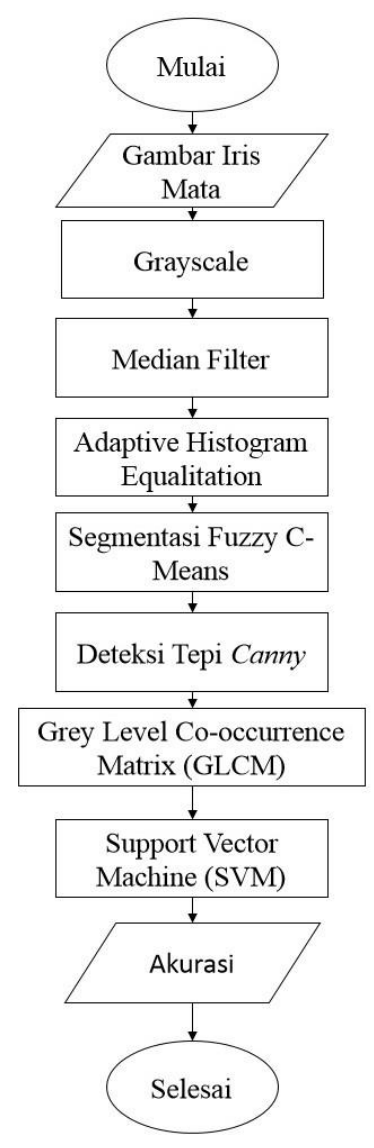

\section{Gambar 3.Diagram Alir Proses Klasifikasi Kelainan Jantung}

Hasil pengolahan citra menggunakan canny edge detection selanjutnya akan diambil beberapa nilai sebagai bentuk ekstraksi fitur dari citra tersebut. Pengambilan beberapa nilai tersebut bilakukan dengan menggunakan metode GLCM. Pada metode GLCM pengambilan nilai untuk ekstraksi fitur dapat dilakukan dari beberapa macam sudut. Mulai dari 0 derajat, 45 derajat, 90 derajat, serta 135 derajat. Dari keempat sudut tersebut akan memiliki nilai yang berbeda beda. Pada penelitian ini ekstraksi fitur akan diambil dari keempat sudut tersebut untuk mewakili pola pola yang terdapat pada citra yang diproses.

Beberapa nilai hasil ekstraksi fitur akan menjadi nilai masukan pada proses klasifikasi. Klasifikasi pada penelitian ini menggunakan metode SVM. Pada tahap klasifikasi citra akan dikelaskan menjadi dua kelas. Citra iris akan dikelaskan menjadi citra dengan kelainan jantung dan citra pada keadaan normal. Proses klasifikasi dilakukan dengan mengambil beberapa gambar sebagai data training dan sisanya sebagai data testing. Pada data training citra yang akan digunakan sebanyak 12 citra. sedangkan pada tahap testing akan menggunakan 8 citra iris. Proses training menggunakan SVM menjadi input pada proses klasifikasi. Dari data yang ada tersebut diproses menggunakan SVM 
untuk mendapatkan hyperplane yang paling optimal.indikator tersebut akan diperoleh hasil klasifikasi dengan nilai yang paling optimal.

\section{Hasil dan Pembahasan}

Klasifikasi dilakukan dengan menggunakan dengan menggunakan gambar yang diperoleh dari klinik kesehatan. Beberapa gambar yang didapat memiliki posisi pemotretan yang berbeda beda. Untuk mengatasi beberapa data tersebut dilakukan proses pemotongan gambar. pemotongan gambar dilakukan untuk semua gambar yang dimiliki. Ukuran yang dihasilkan yaitu 503 x 546 . Ukuran pemotongan dilakukan dari ukuran piksel iris paling besar dari data yang ada. Data yang dimiliki terlebih dahulu dirubah menjadi grayscale. Gambar diubah menjadi graysclae dengan tujuan untuk memperkecil scla yang dimiliki oleh suatu gambar. setelah didapatkan gambar dengan scala abu abu gambar dibersihkan dari nise yang dapat mengganggu klasifikasi. Pembersihan noise pada gambar dilakukan dengan menggunakan median filter. Hasil dari Proses pemotongan dan pembersihan dengan median filter disajikan pada Gambar 4.

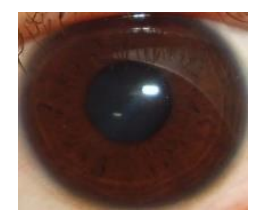

(a)

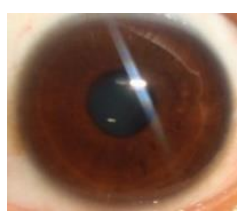

(b)

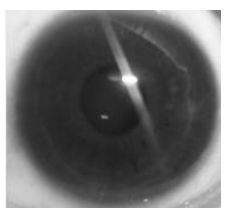

(c)

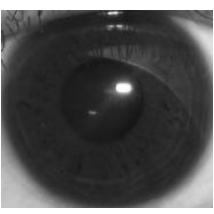

(d)

Gambar 4. (a) Hasil Crop pada Data Mata Normal; (b) Hasil Crop pada Data Mata dengan Kelainan Jantung; (c) Hasil Penghilangan Noise pada Gambar Mata Normal; (d) Hasil Penghilangan Noise pada Gambar Mata dengan Kelainan Jantung

Gambar yang sudah dibersihkan dengan menggunakan median filter selanjutnya ditingkatkan kontras citranya menggunakan Adaptive Histogram Equalitation. Peningkatan kontras pada gambar dilakukan dengan tujuan untuk mendapatkan garis pada iris mata. Menggunakan peningkatan kontras dapat diperjelas garis garis yang dimiliki pada gambar iris. Hasil peningkatan kontras dengan Adaptive Histogram Equalitation tertera pada gambar 5.

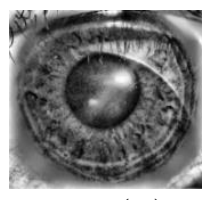

(a)

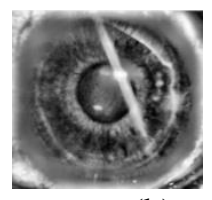

(b)

Gambar 5. (a) Hasil Peningkatan Kontras pada Gambar Mata Normal;

(b) Hasil Peningkatan Kontraspada Gambar Mata dengan Kelainan Jantung.
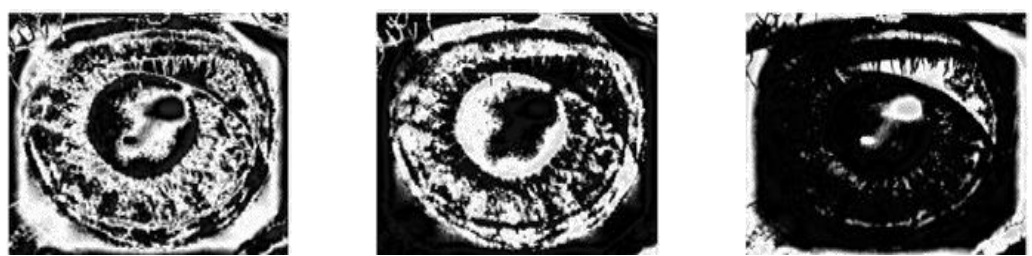

Gambar 6. Hasil Segmentasi Menggunakan Metode Fuzzy C-Means

Untuk mendapatkan fitur iris mata dari data sebelumnya diperlukan adanya segmentasi. Segmentasi tersebut menggunakan Fuzzy C-Means. Segmentasi dilakukan dengan mengambil tiga kelas. Pengambilan tiga kelas ditujukan untuk membedakan 3 fitur berbeda. Pembeda tiga fitur dilakukan dengan membedakan iris mata, bola mata dan warna kulit pada kelopak mata. Hasil dari segmentasi dengan menggunakan Fuzzy C-Means disajikan pada Gambar 6. Hasil dari proses segmentasi dapat dilakukan pembacaan garis tepi pada gambar. Deteksi tepi dilakukan dengan menggunakan deteksi tepi canny. Menggunakan deteksi tepi menghasilkan gambar seperti pada 
Gambar 7. Deteksi tepi menggunakan canny dapat melakukan deteksi garis pada iris mata, tetapi deteksi juga mengenai garis diluar kelopak mata.

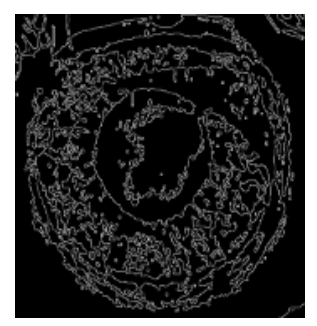

Gambar 7. Hasil Deteksi Tepi Menggunakan Metode Tepi Canny

Tabel 1: Hasil Ekstraksi Fitur Menggunakan GLCM

\begin{tabular}{ccccc}
\hline Data & Kontras & Korelasi & Energi & Homogenitas \\
\hline 1 & 0,11222 & 0,35028 & 0,72765 & 0,94389 \\
\hline 2 & 0,05899 & 0,4188 & 0,84299 & 0,970504 \\
\hline 3 & 0,07198 & 0,39637 & 0,81396 & 0,96401 \\
\hline 4 & 0,07141 & 0,47394 & 0,79792 & 0,96429 \\
\hline 5 & 0,11951 & 0,43037 & 0,68495 & 0,94024 \\
\hline 6 & 0,07284 & 0,4241 & 0,80599 & 0,96358 \\
\hline 7 & 0,06356 & 0,42222 & 0,83047 & 0,96822 \\
\hline 8 & 0,12860 & 0,40827 & 0,6706 & 0,9357 \\
\hline 9 & 0,13454 & 0,35745 & 0,67418 & 0,93273 \\
\hline 10 & 0,1472 & 0,37123 & 0,64037 & 0,9264 \\
\hline 11 & 0,07016 & 0,43193 & 0,81125 & 0,96492 \\
\hline 12 & 0,05809 & 0,55127 & 0,81584 & 0,97096 \\
\hline 13 & 0,09447 & 0,40263 & 0,75631 & 0,95276 \\
\hline 14 & 0,1245 & 0,40803 & 0,68067 & 0,93775 \\
\hline 15 & 0,06877 & 0,40851 & 0,8197 & 0,96562 \\
\hline 16 & 0,11977 & 0,37046 & 0,70432 & 0,94011 \\
\hline 17 & 0,0584 & 0,41178 & 0,8457 & 0,9708 \\
\hline 18 & 0,11899 & 0,37778 & 0,70393 & 0,9405 \\
\hline 19 & 0,14507 & 0,34005 & 0,65616 & 0,92747 \\
\hline 20 & 0,06336 & 0,38917 & 0,83694 & 0,96832 \\
\hline
\end{tabular}

Dari garis garis yang diperoleh pola yang berbeda beda untuk pembacaan kelainan jantung. Pengambilan untuk setiap gambar dilakukan menggunakan metode GLCM. Pada metode GLCM pengambilan fitur dilakukan dengan mengambil beberapa nilai yang merepresentasikan keterkaitan antar piksel pada gambar. Nilai tersebut diantaranya yaitu kontras, energi, homogenitas, dan korelasi pada gambar. setiap data memiliki nilai yang berbeda beda. Beberapa nilai yang didapat dengan menggunakan metode GLCM disajikan pada Tabel 1.

Nilai nilai pada tabel tersebut yang menjadi input pada proses klasifikasi. Dari data pada tabel tersebut diproses menggunakan SVM untuk mendapatkan hyperplane yang paling optimal. Hasil proses SVM menujukkan bahwa akurasi untuk melakukan deteksi kelainan jantung menggunakan citra iris mata dengan segmentasi FCM menghasilkan akurasi sebesar 75\%. Akurasi tersebut didapatkan dari 2 gambar teridentifikasi benar mengalami kelainan jantung, 4 gambar deridentifikasi benar sedang tidak menglami kelainan jantung, 2 gambar salah teridentifikasi salah dengan keadaan sehat, dan 0 gambar teridentifikasi salah untuk gambar mata normal. Pernyataan tersebut ditunjukkan dengan confusion matriks seperti pada Gambar 8. 


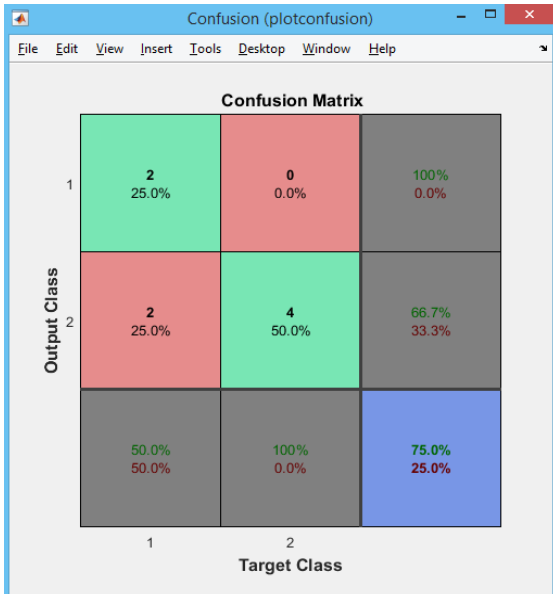

Gambar 8. Hasil Perhitungan Akurasi dengan Confusion Matriks

Dari hasil confusion matriks tersebut mempunyai 2 nilai diagonal utama. Nilai diagonal yang pertama menyatakan jumlah gambar yang teridentifikasi secara benar mengalami kelainan jantung, dan nilai diagonal kedua menyetakan jumlah gambar yang teridentifikasi secara benar tidak mengalami kelainan jantung. Masing masing memiliki nilai 2, dan 4. Mengambil dua nilai diagonal utama tersebut, dapat digunakan untuk menghitung nilai akurasi menggunakan persamaan 11. Sehingga diperoleh hasil akurasi sebesar $75 \%$.

\section{Kesimpulan}

Deteksi kelainan jantung dapat dilakukan dengan menggunakan gambar iris mata. Namun, data untuk melakukan deteksi kelainan jantung dengan iris mata sangat sulit didapatkan. Deteksi kelainan jantung dapat dilakukan dengan segmentasi menggunakan Fuzzy C-Means, hasil akurasi menggunakan Fuzzy C-Means sebesar 75\%

\section{Referensi}

al., P. De Groote et. 2018. "Accuracy of cardiac magnetic resonance imaging to rule out significant coronary artery disease in patients with systolic heart failure of unknown aetiology: Single-centre experience and comprehensive meta-analysis."

Anatomy, V. V. S. Tallapragada and A. I. 2010. "Iris Recognition Based on Combined Feature of GLCM and Wavelet Transform.” 205-210.

B. Kumar, K. Verma, and A. S. Thoke. 2015. "Adaptive gradient descent backpropagation for classification of breast tumors in ultrasound imaging," Procedia - Procedia Comput. Sci." 46: 1601-1609.

Christ, M. C. J. 2011. "“Fuzzy C-Means Algorithm for Medical Image Segmentation.” 33-36.

E. M. K, A. R. Barakbah, S. A. S, and A. A. Hermawan. 2016. "Application For Heart Abnormalities Detection Through Iris." 315-322.

Epar, C. O. S. Ci and E. D. April, 2004. "EXPERIMENTS ON HUMAN IRIS RECOGNITION USING ERROR BACKPROPAGATION ARTIFICIAL NEURAL NETWORK."

Fajrin, Alfannisa Annurullah. 2017. "Optimasi Inventory Produk dan Jumlah Pesanan dengan Fuzzy Logic pada PT. Hilti Nusantara Batam.” Junal Edukasi dan Penelitian Informatika Vol. 3, No. 2, .

Freyssenita Kanditami P, Deni Saipudin, Achmad Rizal. 2014. "ANALISIS CONTRAST LIMITED ADAPTIVE HISTOGRAM EQUALIZATION (CLAHE) DAN REGION GROWING DALAM DETEKSI GEJALA KANKER PAYUDARA PADA CITRA MAMMOGRAM." Elektro 7: 15-28.

Gelley, Ned, ja Jang Roger. 2000. Fuzzy Logic Toolbox. USA: Mathwork, Inc.

J. Zhou, K.L.Chan, V. F. H. Chong, S. M. Krishnan. 2005. "Extraction of Brain Tumor from MR Images Using One-Class Support Vector Machine." Engineering in Medicine and Biology 27th Annual Conference. Shanghai, China.

Jakkula, Vikramaditya. ei pvm. "Tutorial on Support Vector Machine (SVM)."

K. Kesehatan and R. Indonesia. 2018. "Penyakit jantung penyebab kematian tertinggi, kemenkes ingatkan cerdik." 2015-2016. 
Kokare., L. V Birgale and M. 2009. "Iris Recognition Using Discrete Wavelet Transform: Digit. Image Process.” Int. Conf 147-151.

Kusumadewi, Sri. 2002. Analisis dan Desain Sistem Fuzzy Menggunakan Tool Box Matlab. Yogyakarta: Graha Ilmu.

-. 2002. Analisis dan Desain Sistem Fuzzy Menggunakan Tool Box Matlab. Yogyakarta: Graha Ilmu.

Lintang Indah Permatasari, Astri Novianty, S.T, M.T. 2016. ”DETEKSI GANGGUAN ORGAN JANTUNG MENGGUNAKAN KOMPUTERISASI IRIDOLOGI DENGAN METODE KLASIFIKASI SVM Heart Disorder Detection Based on Computerized Iridology Using SVM Classification." 3: 786.

M. Cl. 2018. "Multimodal imaging and three-dimensional cardiac computational modelling in the management of congenital heart disease." 395-398.

M. R. Pokorny et al. 2014. "Prospective study of diagnostic accuracy comparing prostate cancer detection by transrectal ultrasound-guided biopsy versus magnetic resonance (MR) imaging with subsequent mrguided biopsy in men without previous prostate biopsie." 66.

Marbun, Murni \& Tamando, Hengki. 2016. "Perancangan Sistem Perencanaan Jumlah Produksi Roti Menggunakan Metode Mamdani." Jurnal Mantik vol. 20, no. 1.

Olivier Chapelle, Patrick Haffner, and Vladimir N. Vapnik. 1999. "Support Vector Machines for Histogram-Based Image Classification." 10.

P. Matriks, K. A. Keabuan, L. B. Masalah, and I. Mata,. ei pvm. "Pengenalan iris mata menggunakan pencirian matriks ko-okurensi aras keabuan." 1-6.

P. Mohanaiah, P. Sathyanarayana, and L. GuruKumar,. 2013. "Image Texture Fearure Etraction Using GLCM Approach." IJSRP 3.

P. Soepomo. 2014. IMPLEMENTASI METODE CANNY UNTUK DETEKSI 2: 231-243.

Purnomo, Kusumadewi. 2010. Aplikasi Logika Fuzzy Edisi-2. Yogyakarta: Graha Ilmu.

—. 2010. Aplikasi Logika Fuzzy untuk Pendukung Keputusan Edisi-2. Yogyakarta: Graha Ilmu.

Qonita U. Safitri, S.Si, Dr. Arief Fatchul Huda, S.Si, Asep Solih A., M.Si. 2017. "SEGMENTASI CITRA MENGGUNAKAN ALGORITMA FUZZY c-MEANS (FCM) DAN SPATIAL FUZZY c-MEANS (sFCM)."Kubik 2.

R. F. Walker, P. Jackway, B. Lovell, and I. D. Longstaff. ei pvm. "CLASSIFICATION OF CERVICAL CELL NUCLEI USING MORPHOLOGICAL Gray Level CO-Occurrence Matrix Texture Estimates,”.” 297301.

Rahakbauw, Dorteus Lodewyik. 2015. "Penerapan Logika Fuzzy Metode Sugeno Untuk Menentukan Jumlah Produksi Roti Berdasarkan Data Persediaan Dan Jumlah Permintaan.” Jurnal Ilmu Matematika dan Terapan pp. Volume 9 Nomor 2 Hal.121-134.

Ramlan, R, A Cheng, ja dkk. 2016. Implementation of Fuzzy Inference System for Production Planning Optimisation. Malaysia: University Tun Hussein Onn Malaysia.

S. Kumar, J. Kanta, D. Kumar, and M. Nasipuri. 2015. "Conditional spatial fuzzy C-means clustering algorithm for segmentation of MRI images." Appl. Soft Comput. J 34: 758-769.

S.Jayalakshmi. 2014. "A Study of Iris Segmentation Methods using Fuzzy C- Means and K-Means Clustering Algorithm." 85: 1-5.

Yang, G. Y. Peng. 2016. "Accepted Manuscript Reference : To appear in : Neurocomputing," Neurocomputing." 